\title{
Apoptosis of non-parasitized red blood cells in malaria: a putative mechanism involved in the pathogenesis of anaemia
}

\author{
Paulo RR Totino, Aline D Magalhães, Luciene A Silva, Dalma M Banic, Cláudio T Daniel-Ribeiro, \\ Maria de Fátima Ferreira-da-Cruz
}

\begin{abstract}
Background: Severe anaemia is a common complication of Plasmodium falciparum malaria in hyperendemic regions. Premature elimination of non-parasitized red blood cells (nRBC) has been considered as one mechanism involved in the genesis of severe malaria anaemia. It has been reported that apoptosis can occur in RBC and, consequently, this cell death process could contribute to anaemia. This study was performed to evaluate the susceptibility of nRBC to apoptosis in a malaria anaemia murine model.

Methods: Balb/c mice were intraperitonially inoculated with $1 \times 10^{6}$ P. yoelii $17 X L$ parasitized RBC (pRBC) and, then, parasitaemia and anaemia were monitored. Apoptosis in both pRBC and nRBC was assessed during early and late phases of infection by flow cytometry using Syto 16 and annexin V-PE double staining and forward scatter measurement.

Results: As expected, experimental infection of Balb/c mice with Plasmodium yoelii 17XL parasites was characterized by progressive increase of parasitaemia and acute anaemia, leading to death. Flow cytometry analysis showed that a number of pRBC was in the apoptotic process. It was noteworthy that the increase of nRBC apoptosis levels occurred in the late phase of infection, when anaemia degree was notably accentuated, while no significant alteration was observed in the early phase.
\end{abstract}

Conclusion: The increased levels of nRBC apoptosis herein firstly reported, in malaria infection could represent a putative mechanism worsening the severity of malarial anaemia.

\section{Background}

Malaria remains the tropical disease of major prevalence in the world, representing great problem of public health with approximately 250 million cases and 900 thousand deaths annually [1]. From all malaria human parasites, Plasmodium falciparum is the most prevalent and the most frequent parasite species responsible for the severe and lethal forms of the disease. Complications associated to $P$. falciparum infection include severe anaemia, which affects mainly children and pregnant women living in malaria hyperendemic regions $[2,3]$.

The immunological processes involved in malaria anaemia cannot be implicated as the sole cause of

\footnotetext{
* Correspondence: mffcruz@ioc.fiocruz.br

Laboratory of Malaria Research, Instituto Oswaldo Cruz, Fiocruz, Avenida Brasil, 4365, Manguinhos, 21045-900, Rio de Janeiro, RJ, Brasil
}

erythrophagocytosis during malaria [4]. It is well known that, together to mechanical rupture of parasitized red blood cells (pRBC) by the parasite and suppression of erythropoiesis, the premature phagocytosis of nonparasitized RBCs (nRBC) is also a mechanism implicated in the development of severe malaria anaemia $[5,6]$.

Apoptosis - a physiological process of programmed cell death related to nucleated cells - can also occur in $\mathrm{RBC}$ as a result of intracellular influx of $\mathrm{Ca}^{2+}$, which leads to cell shrinkage, membrane blebbing, phosphatidylserine exposure and protease activation [7]. Although apoptosis is an essential phenomenon for cell populations regulation it was also engaged in elimination of damaged, infected and mutated cells as well as in the genesis of many disorders [8,9]. Enhanced levels of RBC apoptosis have been observed in clinical disorders in
Ciomed Central

C 2010 Totino et al; licensee BioMed Central Ltd. This is an Open Access article distributed under the terms of the Creative Commons Attribution License (http://creativecommons.org/licenses/by/2.0), which permits unrestricted use, distribution, and reproduction in any medium, provided the original work is properly cited. 
which anaemia is a common feature, such as iron and G6PD deficiency, renal insufficiency, thalassaemia, sickle-cell disease and sepsis [7] and in malaria infection apoptosis has been associated to cerebral malaria, thrombocytopenia and lymphocytopaenia [10-12]. The apoptosis of parasitized RBC does exists and it is also possible that the same phenomenon could concern normal RBC and RBC apoptosis could, therefore, contribute to the genesis of malaria anaemia. In this light, the present study was carried out to evaluate the susceptibility of $n R B C$ to apoptosis in a murine model of malaria anaemia.

\section{Methods}

\section{Experimental infection}

The lethal experimental infection of Balb/c mice with Plasmodium yoelii 17XL parasites was used as a malaria anaemia model. Where indicated, non-infected, agematched mice were used as control. All animal experimentation was approved by the Ethics Committee on the Use of Animals of the Oswaldo Cruz Foundation (Fiocruz), Rio de Janeiro, RJ, Brazil.

For infection, female Balb/c mice aged 6-8 weeks, provided by the Centre for Laboratory Animals Breeding of the Fiocruz, were intraperitoneally inoculated with $1 \times$ $10^{6}$ P. yoelii $17 \mathrm{XL}-\mathrm{pRBC}$ in $0.2 \mathrm{~mL}$ phosphate buffered saline (PBS). During infection, parasitaemia and anaemia degree were routinely monitored through mice tail blood samples. Parasitaemia was determined by counting the number of pRBC in a total count of $1000 \mathrm{RBC}$ in thin blood smears stained by the Romanowski's method (Panótico Rápido, Laborclin ${ }^{\circ}$ Pinhais, PR, Brazil). Anaemia was evaluated by counting the number of $\mathrm{RBC} / \mathrm{mm}^{3}$ of blood. Briefly, $2 \mu \mathrm{L}$ of blood were suspended in $0.5 \mathrm{~mL}$ heparinized PBS, diluted 1:10 in the same buffer and, then, the number of RBC determined in a haemocytometer.

\section{Apoptosis assay}

Apoptosis was identified in the early (day 4 ) and late (days 6-7) phases of P. yoelii infection through the detection of phosphatidylserine exposure (PS) at the cell surface and cell shrinkage [7]. For this propose, it was used Syto 16 and annexin V-PE double staining that identify pRBC and PS exposure, respectively. Briefly, $\mathrm{RBC}$ were isolated from mice tail heparinized blood by centrifugation at $350 \times \mathrm{g}$ for $10 \mathrm{~min}$ at room temperature, washed twice with PBS and, then, incubated at $37^{\circ} \mathrm{C}$ for $40 \mathrm{~min}$ at a density of $1 \times 10^{5}$ cells $/ 400 \mu \mathrm{L}$ in PBS containing $100 \mathrm{nM}$ Syto 16 (Invitrogen). After incubation, staining buffer was discarded and the RBC were stained with $5 \mu \mathrm{L}$ annexin $\mathrm{V}$ (BD Pharmingen) for $15 \mathrm{~min}$ at room temperature in $100 \mu \mathrm{L}$ annexin-binding buffer (BD Pharmingen) containing $100 \mathrm{nM}$ Syto 16.
Finally, cells were five times diluted in annexin-binding buffer containing Syto 16 and both forward scatter and fluorescence emission were assessed using a flow cytometer (FACScalibur, Becton Dickinson)

In addition to ex-vivo analysis, apoptosis was also measured after incubation of $\mathrm{RBC}$ for $24 \mathrm{~h}$ at $37^{\circ} \mathrm{C}$ at a haematocrit of $0.5 \%$ in Ringer solution containing (in $\mathrm{mM}$ ) $125 \mathrm{NaCl}, 5 \mathrm{KCl}, 1 \mathrm{MgSO}_{4}, 32 \mathrm{~N}$-2-hydroxyethylpiperazine- $\mathrm{N}-2$-ethanesulfonic acid (HEPES), 5 glucose, and $1 \mathrm{CaCl}_{2}(\mathrm{pH}$ 7.4).

\section{Statistical analysis}

Statistical analyses were performed using t student test in GraphPad Prism 5.0 software (San Diego, CA, USA); a p-value $<0.05$ was considered significant.

\section{Results and discussion}

Data from experimental rodent malaria infection, widely used as malaria models, have reinforced premature destruction of $\mathrm{nRBC}$ as a relevant process of malaria anaemia $[13,14]$. Thus, to investigate the involvement of $\mathrm{nRBC}$ apoptosis in malaria anaemia a $P$. yoelii $17 \mathrm{XL}$ malaria murine model was used in the present report.

As expected, P. yoelii 17XL infection was marked by an accentuated anaemia degree and it was lethal to Balb/c mice $[15,16]$. Infected mice started to die on day 7 post-infection with parasitaemia rates of $60,7 \pm 13,3 \%$ on the day preceding the death (Figure $1 \mathrm{~A}$ ). The progression of infection was accompanied by a decline in the number of peripheral RBC, leading to acute anaemia, characterized by a drop of around $73 \%$ in the number of RBC, when compared to non-infected control mice (Figure 1B).

Since pathogens have the capacity to induce apoptosis in both infected and non-infected host cells, influencing the pathogenesis of disease $[8,17]$, it was firstly examined if the late phase of $P$. yoelii 17XL infection, when anaemia degree was accentuated, was marked by RBC apoptosis. As expected, a percentage of $P$. yoelii-pRBC exposing PS and, therefore, undergoing apoptosis (Figure 2A) was observed, as reported in P. falciparumand Plasmodium berghei-pRBC $[18,19]$. However, it is noteworthy that malaria infection also significantly increased the levels of $\mathrm{nRBC}$ exposing PS both ex-vivo and after $24 \mathrm{~h}$ in vitro culture, when compared with non-infected control mice $(\mathrm{p}<0.05)$ (Figures $2 \mathrm{~B}$ and $2 \mathrm{C})$. Pro-apoptotic potential of malaria was further reinforced by forward scatter analysis, which showed that $P$. yoelii 17XL also induced significant cell shrinkage of nRBC $(\mathrm{p}<0.05)$ (Figure 3). Conversely, when both PS exposure and cell shrinkage were assessed during early phase of infection, it was not possible to identify significant alteration in the rates of apoptotic nRBC $(p>0.05)$ (Figure 4). 

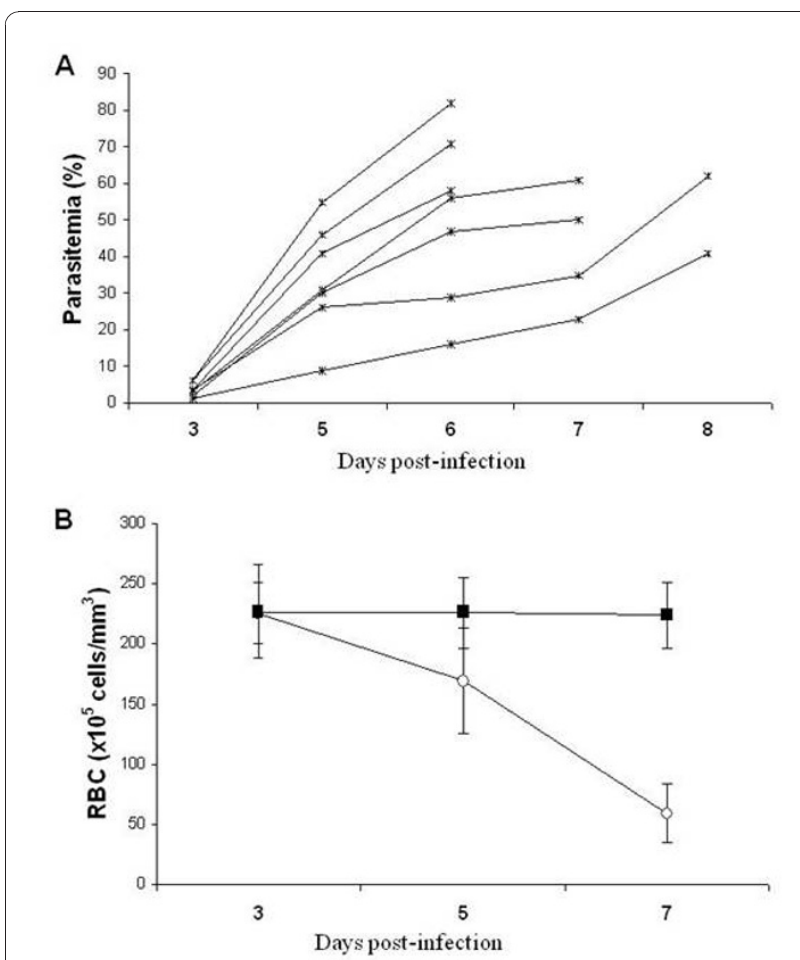

Figure 1 Course of parasitaemia and progression of anaemia in $P$. yoelii $17 \mathrm{XL}$ infected Balb/c mice. Mice $(n=7)$ were inoculated with $10^{6}$ P. yoelii $17 X \mathrm{~L}-\mathrm{pRBC}$ and parasitaemia and anaemia degree were measured. In parallel, non-infected, agematched mice were used as control $(n=5)$. (A) Individual parasitaemia in infected mice on days 3 and 5-8 post-infection. (B) Means \pm SD of the number of RBC/ $\mu \mathrm{L}$ of blood in infected (open circles) and non-infected (closed squares) mice on days 3, 5 and 7 post-infection. Data are representative of two separate experiments.

The apoptotic process in $\mathrm{pRBC}$ has been described as a result of intraerythrocytic plasmodia development. During schizogony, malaria parasites activate non-selective cation channel in host RBC membrane, allowing entry of $\mathrm{Ca}^{2+}$ and $\mathrm{Na}^{+}$necessary for its intracellular growth [20]. Sequentially, intracellular $\mathrm{Ca}^{2+}$ influx leads to activation of phospholipid scramblase and $\mathrm{Ca}^{2+}$-sensitive $\mathrm{K}^{+}$channels responsibles to PS exposure at outer membrane leaflet and cell shrinkage, respectively [21]. If one take in mind that apoptotic cells are quickly recognized and removed by phagocytes [22], apoptosis could act controlling parasite proliferation and even confer partial protection in sickle-cell trait carriers through accelerated clearance of ring-stage pRBC apoptosis [23].

However, if the augmented elimination of $\mathrm{nRBC}$ (for each $\mathrm{pRBC}$, nine $\mathrm{nRBC}$ were removed) in both human and experimental malaria $[13,24,25]$ could be due, at least in part, by erythrocytic apoptosis, PS exposure could also adversely promote elimination of nRBC, contributing also to malaria anaemia pathogenesis. This hypothesis could be supported by the report that

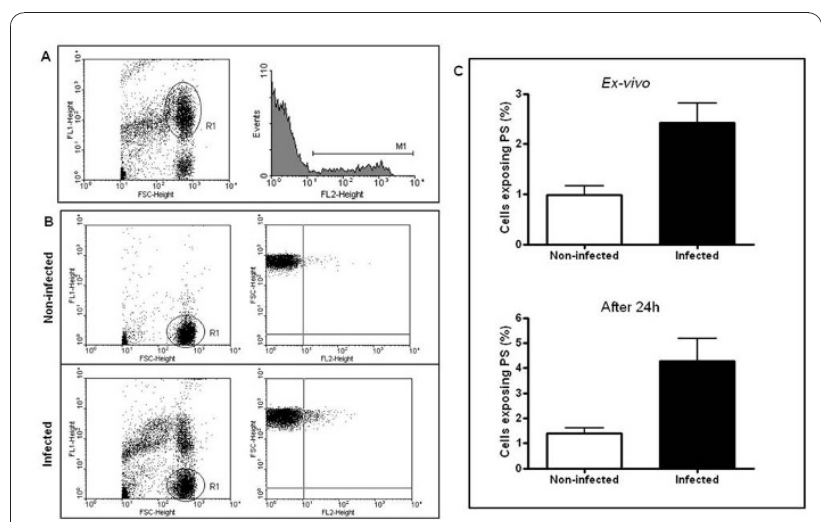

Figure 2 Phosphatidylserine (PS) exposure in pRBC and $n R B C$ during $P$. yoelii $17 \mathrm{XL}$ infection. Balb/c mice $(n=5)$ were infected with $10^{6}$ P. yoelii $17 \mathrm{XL}-\mathrm{pRBC}$ and, than, PS exposure was evaluated in the late stage of infection by flow cytometry using Syto 16 (FL-1) and annexin V-PE (FL-2) dual staining. In parallel, non-infected, agematched mice were used as control $(n=4)$. (A) Representative flow cytometry analysis of pRBC exposing PS in infected mice. (B) Representative flow cytometry analysis of nRBC exposing PS in infected and non-infected mice. (C) Means \pm SEM of levels of nRBC exposing PS in infected and non-infected mice detected ex-vivo and after $24 \mathrm{~h}$ culture. Data are representative of three separate experiments.

deficiency of PS receptor operating in phagocytosis (i.e., CD36) can confer protection against malaria anaemia in children infected with $P$. falciparum [26].

Since $\mathrm{nRBC}$ apoptosis was increased during only the late phase of malaria infection, one may wonder which factors could be implicated to its induction? Notably,

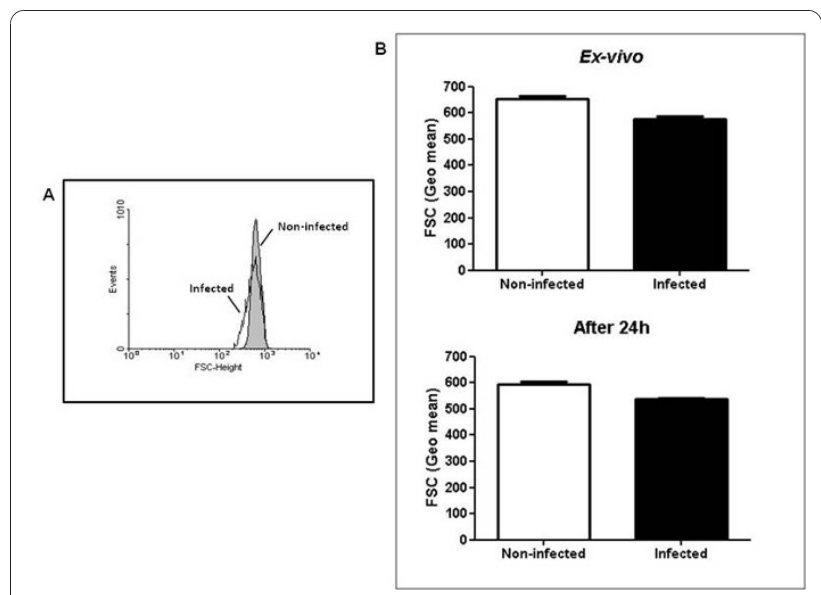

Figure 3 Cell shrinkage in $\mathrm{nRBC}$ during $P$. yoelii $17 \mathrm{XL}$ infection. Balb/c mice $(n=5)$ were infected with $10^{6}$ P. yoelii $17 X L-p R B C$ and, than, RBC forward scatter was determined in the late stage of infection by flow cytometry. (A) Representative flow cytometry analysis of the nRBC forward scatter in infected and non-infected mice. (B) Means \pm SEM of the geometric mean of the nRBC forward scatter in infected and non-infected mice detected ex-vivo and after $24 \mathrm{~h}$ culture. Data are representative of tree separate experiments. 

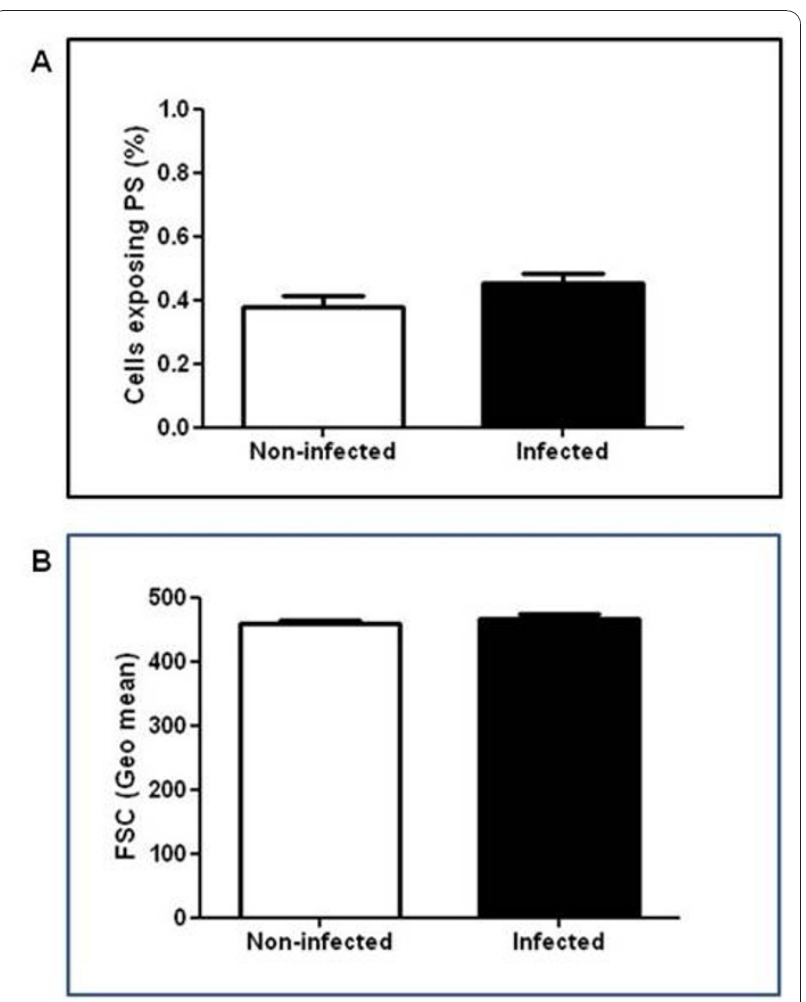

Figure 4 Phosphatidylserine (PS) exposure and cell shrinkage in $\mathrm{nRBC}$ during early stage of $P$. yoelii $17 \mathrm{XL}$ infection. Balb/c

mice $(n=5-7)$ were infected with $10^{6} P$. yoelii $17 X L-p R B C$ and, than, PS exposure and forward scatter was evaluated in the early stages of infection by flow cytometry. Data show means \pm SEM of ex-vivo levels of $n R B C$ exposing PS (A) and of the $\mathrm{nRBC}$ forward scatter (B) in infected and non-infected mice. Data are representative of two separate experiments.

different types of RBC apoptosis-inducer, such as antiRBC antibodies, oxidative stress and parasite antigens, are associated to malaria infection [7]. Indeed, antierythrocyte auto-antibodies and nitric oxide production are increased during plasmodia infection and they can be associated to anaemia severity $[14,27,28]$. Soluble factors from P. falciparum-pRBC are also capable of inducing apoptosis in endothelial and neuroglia cells [29] and bystander $\mathrm{nRBC}$ in P. falciparum in vitro culture undergo apoptotic process [30]. Moreover, defective production of erythropoietin - a RBC apoptosis inhibitor [31] - has been also associated with acute anaemia in malaria [32]. Thus, both host immune and parasitederived factors, could be implicated to $\mathrm{nRBC}$ apoptosis during severe malaria anaemia state.

Finally, since ex vivo $\mathrm{pRBC}$ and $\mathrm{nRBC}$ are capable of exposuring PS and these cells were not significantly sequestrated at the present study, it is presumable that the simple presence of PS is not enough for in vivo endothelium adhesion, as previously suggested in in vitro-measured adhesiveness studies with both
pRBC and nRBC $[18,33,34]$. Further studies on in vivo adherence capacity of apoptotic RBC on endothelium are necessary to clarify the role of PS, besides $P$. falciparum erythrocyte membrane protein 1 (PfEMP1), in cerebral and placental malaria pathogenesis. Intra-vital microscopy studies could help for clarifying these questions.

\section{Conclusion}

The present report showed for the first time that malaria infection increase the levels of $\mathrm{nRBC}$ apoptosis, a process that could represent a putative mechanism worsening the severity of malaria anaemia. Attempts to decipher immune and parasitic factors related to RBC apoptosis during the course of malaria infection are currently underway on rodent and human malaria.

\section{Acknowledgements}

This work was financially supported by Instituto Oswaldo Cruz-Fiocruz and by Fundação de Amparo à Pesquisa do Estado do Rio de Janeiro (Faperj).

\section{Authors' contributions}

PRRT participated in the design of the study, carried out the animal experimentation, flow cytometry and data analysis and drafted the manuscript. ADM and LAS helped in animal experimentation and carried out parasitaemia and anaemia measurements. DMB provided characterized parasite strains and revised the manuscript. CTDR helped in the design of the study and revised the manuscript. MFFC conceived the study, coordinated its design, and finalized the manuscript. All authors read and approved the final manuscript.

\section{Competing interests}

The authors declare that they have no competing interests.

Received: 30 July 2010 Accepted: 2 December 2010 Published: 2 December 2010

\section{References}

1. World Health Organization: World Malaria Report. Geneva: WHO; 2008.

2. Menendez C, Fleming AF, Alonso PL: Malaria-related anaemia. Parasitol Today 2000, 16:469-476.

3. Casals-Pascual C, Roberts DJ: Severe malarial anaemia. Curr Mol Med 2006, 6:155-168.

4. Abdalla SH: Peripheral blood and bone marrow leucocytes in Gambian children with malaria: numerical changes and evaluation of phagocytosis. Ann Trop Paediatr 1988, 8:250-258.

5. Chang KH, Stevenson MM: Malarial anaemia: mechanisms and implications of insufficient erythropoiesis during blood-stage malaria. Int J Parasitol 2004, 34:1501-1516.

6. Lamikanra AA, Brown D, Potocnik A, Casals-Pascual C, Langhorne J, Roberts DJ: Malarial anemia: of mice and men. Blood 2007, 110:18-28.

7. Föller M, Huber SM, Lang F: Erythrocyte programmed cell death. IUBMB Life 2008, 60:661-668.

8. Dockrell DH: Apoptotic cell death in the pathogenesis of infectious disease. J Infect 2001, 42:227-234.

9. Fadeel B, Orrenius S: Apoptosis: a basic biological phenomenon with wide-ranging implications in human disease. J Intern Med 2005, 258:479-517.

10. Piquet PF, Kan CD, Vesin C: Thrombocytopenia in an animal model of malaria is associated with an increased caspase-mediated death of thrombocytes. Apoptosis 2002, 7:91-98.

11. Riccio EKP, Júnior IN, Riccio LRP, Alecrim MG, Corte-Real S, Morgado M, Daniel-Ribeiro CT, Ferreira-da-Cruz MF: Malaria associated apoptosis is not significantly correlated with either parasitemia or the number of previous malaria attacks. Parasitol Res 2003, 90:9-18. 
12. Touré FS, Ouwe-Missi-Oukem-Boyer O, Bisvigou U, Moussa O, Rogier $C$, Pino P, Mazier D, Bisser S: Apoptosis: a potential triggering mechanism of neurological manifestation in Plasmodium falciparum malaria. Parasite Immunol 2008, 30:47-51.

13. Salmon MG, Souza JB, Butcher GA, Playfair JHL: Premature removal of uninfected erythrocytes during malarial infection of normal and immunodeficient mice. Clin Exp Immunol 1997, 108:471-476.

14. Helegbe GK, Huy NT, Yanagi T, Shuaibu MN, Yamazaki A, Kikuchi M, Yasunami M, Hirayama K: Rate of red blood cell destruction varies in different strains of mice infected with Plasmodium berghei-ANKA after chronic exposure. Malar J 2009, 8:91.

15. Weiss $L$ : Mechanisms of splenic control of murine malaria: cellular reactions of the spleen in lethal (strain 17XL) Plasmodium yoelii malaria in BALB/c mice, and the consequences of pre-infective splenectomy. Am J Trop Med Hyg 1989, 41:144-160.

16. Wang QW, Liu Y, Liu J, Chen G, Zheng W, Wang J, Cao Y: Plasmodium yoelii: assessment of production and role of nitric oxide during the early stages of infection in susceptible and resistant mice. Exp Parasitol 2009, 121:268-273.

17. Labbé K, Saleh M: Cell death in the host response to infection. Cell Death Differ 2008, 15:1339-1349.

18. Eda S, Sherman IW: Cytoadherence of malaria-infected red blood cells involves exposure of phosphatidylserine. Cell Physiol Biochem 2002, 12:373-384.

19. Koka S, Lang C, Boini KM, Bobbala D, Huber SM, Lang F: Influence of chlorpromazine on eryptosis, parasitemia and survival of Plasmodium berghei infected mice. Cell Physiol Biochem 2008, 22:261-268.

20. Lang F, Lang PA, Lang KS, Brand V, Tanneur V, Duranton C, Wieder T, Huber SM: Channel-induced apoptosis of infected host cells-the case of malaria. Pflugers Arch 2004, 448:319-324.

21. Bevers EM, Williamson PL: Phospholipid scramblase: An update. FEBS Lett 2010, 584:2724-2730

22. Fadok VA: Phagocyte receptors for apoptotic cells: recognition, uptake, and consequences. J Clin Invest 2001, 108:957-962.

23. Lang PA, Kasinathan RS, Brand VB, Duranton C, Lang C, Koka S, Shumilina E, Kempe DS, Tanneur V, Akel A, Lang KS, Foller M, Kun JF, Kremsner PG, Wesselborg S, Laufer S, Clemen CS, Herr C, Noegel AA, Wieder T, Gulbins E, Lang F, Huber SM: Accelerated clearance of Plasmodium-infected erythrocytes in sickle cell trait and annexin-A7 deficiency. Cell Physiol Biochem 2009, 24:415-428.

24. Looareesuwan S, Davis TME, Pukrittayakamee S, Supanaranond W, Desakorn V, Silamut K, Krishna S, Boonamrung S, White NJ: Erythrocyte survival in severe falciparum malaria. Acta Trop 1991, 48:263-270.

25. Jakeman GN, Saul A, Hogarth WL, Collins WE: Anaemia of acute malaria infections in non-immune patients primarily results from destruction of uninfected erythrocytes. Parasitology 1999, 119:127-133.

26. Chilongola J, Balthazary S, Mpina M, Mhando M, Mbugi E: CD36 deficiency protects against malarial anaemia in children by reducing Plasmodium falciparum-infected red blood cell adherence to vascular endothelium. Trop Med Int Health 2009, 14:810-816.

27. Waitumbi JN, Opollo MO, Muga RO, Misore AO, Stoute JA: Red cell surface changes and erythrophagocytosis in children with severe Plasmodium falciparum anemia. Blood 2000, 95:1481-1486.

28. Keller CC, Kremsner PG, Hittner JB, Misukonis MA, Weinberg JB, Perkins DJ: Elevated nitric oxide production in children with malaria anemia: hemozoin-induced nitric oxide synthase type 2 transcription and nitric oxide in blood mononuclear cells. Infect Immun 2004, 72:4868-4873.

29. Wilson NO, Huang MB, Anderson W, Bond V, Powell M, Thompson WE, Armah HB, Adjei AA, Gyasi R, Tettey Y, Stiles JK: Soluble factors from Plasmodium falciparum-infected erythrocytes induce apoptosis in human brain vascular endothelial and neuroglia cells. Mol Biochem Parasitol 2008, 162:172-176.

30. Pattanapanyasat K, Sratongno P, Chimma P, Chitjamnongchai S, Polsrila K, Chotivanich K: Febrile temperature but not proinflammatory cytokines promotes phosphatidylserine expression on Plasmodium falciparum malaria-infected red blood cells during parasite maturation. Cytometry $A$ 2010, 77:515-523.

31. Myssina S, Huber SM, Birka C, Lang PA, Lang KS, Friedrich B, Risler T, Wieder T, Lang F: Inhibition of erythrocyte cation channels by erythropoietin. J Am Soc Nephrol 2003, 14:2750-2757.
32. Vedovato M, De Paoli Vitali E, Dapporto M, Salvatorelli G: Defective erythropoietin production in the anaemia of malaria. Nephrol Dial Transplant 1999, 14:1043-1044.

33. Butthep P, Wanram S, Pattanapanyasat K, Vattanaviboon P, Fucharoen S, Wilairat P: Cytoadherence between endothelial cells and $P$. falciparum infected and noninfected normal and thalassemic red blood cells. Cytometry B Clin Cytom 2006, 70:432-442.

34. Setty BNY, Betal SG: Microvascular endothelial cells express a phosphatidylserine receptor: a functionally active receptor for phosphatidylserine-positive erythrocytes. Blood 2008, 111:905-914.

doi:10.1186/1475-2875-9-350

Cite this article as: Totino et al:: Apoptosis of non-parasitized red blood cells in malaria: a putative mechanism involved in the pathogenesis of anaemia. Malaria Journal 2010 9:350.

\section{Submit your next manuscript to BioMed Central and take full advantage of:}

- Convenient online submission

- Thorough peer review

- No space constraints or color figure charges

- Immediate publication on acceptance

- Inclusion in PubMed, CAS, Scopus and Google Scholar

- Research which is freely available for redistribution

Submit your manuscript at www.biomedcentral.com/submit
Biomed Central 